\title{
PerCursos
}

\section{Marco temporal, Supremo Tribunal Federal e direitos dos povos indígenas: um retrocesso anunciado}

\section{Resumo}

O presente artigo busca demonstrar a tese do marco temporal como desconstrução do novo paradigma presente na Constituição Federal de 1988 a respeito dos povos indígenas. Até a Constituição de 1988 era reconhecido, de certo modo, o direito dos povos indígenas às suas terras, mas não o direito a permanecer indígena; assim, a integração era vista como necessária. Em 1988, esse paradigma muda, e a integração é deixada de lado na lei. Aos povos indígenas é reconhecido o direito de ser e permanecer sendo, além do reconhecimento do direito originário às terras que ocupam. Tal reconhecimento se deu, principalmente, por conta da luta dos povos indígenas que há 520 anos resistem. Contudo, o Supremo Tribunal Federal criou a tese do marco temporal, que implica dizer que um povo indígena somente tem direito ao seu território se lá estivesse em cinco de outubro de 1988. Assim, o maior tribunal do país desconsidera a luta dos povos e a violência que os expulsou por tantas vezes de suas terras. Portanto, o objetivo central é analisar de forma crítica a tese do marco temporal, demonstrando que é contrária à própria Constituição e desconsidera a luta e resistência dos povos. Para isso, faz-se uma análise histórica do direito dos povos indígenas, apresenta-se o julgado destacando os votos dos Ministros e, então, num terceiro momento, apresentam-se argumentos que demonstram que a tese do marco temporal significa, em certa medida, a volta do ideal da integração e uma mitigação dos direitos dos povos indígenas.

Palavras-chave: Povos Indígenas. Marco Temporal. Terras tradicionais.
Rachel Dantas Libois

Mestranda em Direito na Área de Direito Socioambiental e

Sustentabilidade na Pontifícia Universidade Católica do Paraná

- PUC PR.

Brasil

rachel.libois@hotmail.com

\section{Robson José da Silva}

Mestre e Doutor em Direito pela Universidade Federal do Paraná UFPR. Professor da Universidade Estadual de Ponta Grossa - UEPG.

Brasil

jrsrobson@uol.com.br

\footnotetext{
Para citar este artigo:

LIBOIS, Rachel Dantas; SILVA, Robson José da. Marco temporal, Supremo Tribunal Federal e direitos dos povos indígenas: um retrocesso anunciado. PerCursos, Florianópolis, v. 22, n.48, p. 399 - 429, jan./abr. 2021.
}

DOI: 10.5965/1984724622482021399

http://dx.doi.org/10.5965/1984724622482021399 


\title{
Temporal milestone, Supreme Federal Court and indigenous people rights: a return announced
}

\begin{abstract}
This study seeks to demonstrate the thesis of the Temporal Milestone as a deconstruction of the new paradigm in the Federal Constitution of 1988 concerning indigenous peoples. Until the 1988 Constitution, the right of indigenous people to their lands was recognized to some extent, but not the right to remain indigenous, so integration was seen as necessary. In 1988 this paradigm changes and the law sets integration aside. Indigenous peoples are recognized the right to be and to remain indigenous, in addition to the recognition of their original right to the lands they occupy. Such recognition came about, mainly because of the indigenous people's struggle, which has been resisting for 520 years. However, the Supreme Court created the thesis of the temporal landmark, which implies that an indigenous people only has the right to its territory if it was there on October 5th, 1988. Thus, the highest court in the country disregards the peoples' struggle and the violence that has driven them from their lands so many times. Therefore, the main objective is to critically analyze the Temporal Milestone thesis, demonstrating that it is against the constitution itself and disregards the peoples' struggle and resistance. To this end, we carried out a historical analysis of the indigenous peoples' rights, we presented the decision, highlighting the Justices' votes. Then, in a third moment, we presented arguments that demonstrate that the temporal milestone thesis means, to a certain extent, the return of the integration ideal and mitigation of the indigenous peoples' rights.
\end{abstract}

Keywords: Indigenous peoples. Temporal Milestone. Tradicional lands. 


\section{Apontamentos introdutórios}

O Relatório da Violência Contra os Povos Indígenas, com dados de 2019, e realizado pelo Conselho Indigenista Missionário (CIMI, 2020, p. 53) apontou que de um total de 1.298 terras indígenas ( $\mathrm{TI}$ ) existentes no país, 829 possuem alguma pendência administrativa, ou seja, não estão devidamente demarcadas e registradas no cartório de registros respectivo. O relatório aponta que o lento ritmo de demarcações iniciado no $2^{\circ}$ Governo da Presidenta Dilma se mantém. Michel Temer demarcou uma TI e o decreto homologatório foi suspenso por ordem judicial, e Jair Bolsonaro não demarcou nenhuma.

O Cimi (2020, p. 50) denunciou que a situação se tornou pior quando 27 procedimentos demarcatórios que aguardavam o decreto presidencial - o último ato para demarcação - foram devolvidos ao Ministério da Justiça para serem adequados à tese do marco temporal da ocupação.

Eloy Terena (AMADO, 2020) explica que a tese do marco temporal encontrou campo fértil no judiciário, mas que já era presente nos discursos de parlamentares e juristas defensores dos interesses do capital antes mesmo do caso Raposa Serra do Sol. A tese do marco temporal ganha destaque em 2009 com o julgamento da Pet. 3.388 pelo Supremo Tribunal Federal (STF) - que trata da TI Raposa Serra do Sol, momento em que também foram criadas 19 condicionantes aos direitos constitucionais dos povos indígenas.

Após três anos do julgamento, no ano de 2012, a Advocacia-Geral da União (AGU) emitiu a Portaria 303 que determinava que a tese do marco temporal e as 19 condicionantes deveriam ser aplicadas a toda administração pública direta e indireta ao tratar dos direitos do povos indígenas. Entre vai-e-volta, a portaria foi suspensa e enviada para consulta. Em 2017, ela retorna por meio do Parecer 001/17 emitido pela AGU. Atualmente, os efeitos do parecer encontram-se suspensos pelo próprio STF.

Nesse contexto, busca-se analisar a tese do marco temporal frente ao reconhecimento de direitos dos povos indígenas presente na Constituição, que abandonou o ideal da integração e reconheceu aos povos indígenas não somente o direito originário à terra, mas também o direito a ser e permanecer indígena. 
Para atingir tal feito é necessário apresentar e analisar a história de reconhecimento dos direitos dos povos indígenas de modo a evidenciar o caráter integracionista das legislações até 1988. Então, apresentam-se trechos dos votos dos Ministros na Pet. 3.388/RR em que tratam do marco temporal, visando destacar quais os argumentos trazidos por eles. Por fim, analisa-se de forma crítica os votos confrontandoos com as referências bibliográficas apresentadas no trabalho, de modo a demonstrar que a tese do marco temporal é um retrocesso no reconhecimento e efetivação dos direitos dos povos indígenas e, portanto, quebra o novo paradigma trazido na Constituição de 1988.

\section{Breve histórico dos direitos dos povos indígenas}

No início das invasões europeias no século XVI havia entre cinco e seis milhões de habitantes espalhados por todo território brasileiro (COELHO DOS SANTOS, 2005, p. 74). O censo realizado em 2010 pelo Instituto Brasileiro de Geografia e Estatística (IBGE) apontou que havia cerca de 896,9 mil indígenas, 305 etnias e 274 línguas. Isso significa dizer que houve uma redução de aproximadamente $82 \%$ da população.

Alberto Passos Guimarães (1968, p. 11) explica que os povos que já habitavam o Brasil antes da colonização entendiam que a terra pertencia a todos. O autor complementa afirmando que os agentes colonizadores utilizavam métodos de conquista que visavam tornar os indígenas nativos submissos e dóceis, para transformá-los em mão de obra barata e tomar para si suas terras. Buscava-se a terra para plantio e as populações para mão de obra.

Não obstantes os apelos da Igreja, como aponta o autor (GUIIMARÃES, 1968, p. 15), evidenciados na bula papal Sublimis Deus, emitida pelo Papa Paulo III, em 1537, que recomendava a não escravização dos indígenas, a busca por mão de obra continuou forçando diversos povos a fugirem "Brasil adentro", abandonando suas terras e buscando esconder-se do colonizar. Mesmo com os apelos dos religiosos, a colonização seguiu deixando sua marca e o rastro de sangue das populações nativas. 
Nesse contexto de invasão de terras e escravização dos povos originários, Guimarães (1968, p. 51) explica que Portugal passou a se utilizar do sistema das sesmarias que dividiu o território brasileiro em capitanias que permitiam ao dono expedir espécies de contratos com os colonos, tornando-os subordinados ao dono da terra e a Portugal. 0 autor alerta que a divisão das terras se dava privilegiando os portugueses mais ricos. Concluindo, afirma que:

Sob o signo da violência contra as populações nativas, cujo direito congênito à propriedade da terra nunca foi respeitado e muito menos exercido, é que nasce e se desenvolve o latifúndio no Brasil. Dêsse estigma de ilegitimidade que é o seu pecado original, jamais ele se redimiria. (PASSOS, 1968, p. 19)

Guimarães (1968, p. 15) explica que a violência era tamanha que no próprio reino começaram a surgir protestos, contudo temia-se não o extermínio dos indígenas, mas o extermínio das "reservas nativas de braços". Passados alguns anos, a metrópole tratou dos povos indígenas na Carta Régia de 1611; eram tratados como gentios e declarava-se que:

E os ditos Gentios serão senhores de suas fazendas nas povoações, assim como o são na Serra, sem lhes poderem ser tomadas, nem sobre ellas se Ihes fazer molestia, ou injustiça alguma; nem poderão ser mudados contra suas vontades das Capitanias e logares, que lhes forem ordenados, salvo quando elles livremente o quiserem fazer. (PORTUGAL, 1611)

O Estado português declarava que os povos indígenas tinham o direito de permanecer em suas terras, no entanto, visava à integração. Para tanto, deveria haver a sua “conversão á nossa santa fé Catholica” (PORTUGAL, 1611). Guimarães (1968, p. 16) cita também o Alvará de $1^{\circ}$ de abril de 1680, que reconheceu os indígenas como senhores de suas terras e, posteriormente, a Lei de 06 de junho de 1755, editada pelo Marquês de Pombal - que reafirmou a normativa anterior. Mas nada mudou; a violência pela busca de 
mão de obra escrava e a busca pela apropriação de terras das comunidades continuou de forma violenta.

Marés (SOUZA FILHO, 2018, p. 79) explica que, enquanto nas metrópoles Portugal e Espanha alguns direitos eram garantidos aos trabalhadores, nas colônias desconsiderava-se qualquer direito dos povos à terra e a sua organização social; visava-se sua integração ao trabalho e este se dava de forma escravagista. Desse modo, entendiase "estar" indígena, ou seja, o indivíduo indígena seria logo incorporado à sociedade e se tornaria mão de obra, daí a razão porque se reconhecia o direito à terra, mas não o direito a ser indígena. Entendia-se ser necessário proteger a terra somente enquanto perdurasse o "estado" indígena, desconsiderando toda uma estrutura social, costumes, línguas e direitos coletivos que existiam.

Já após a independência, em 1831, o Estado Brasileiro exonerou todos os indígenas da servidão, e em 1845, regulamentou as missões de catequese e civilização desses povos. Criou-se uma estrutura administrativa para tratar a questão; no entanto, grande parte da responsabilidade continuava recaindo sobre a Igreja, que possuía uma visão integracionista, a qual se concretizava por meio da catequização (SOUZA FILHO, 2012, p. 88), de forma que o ideal da integração que norteou a relação da Metrópole com os povos indígenas das colônias se manteve após a independência.

Marés (SOUZA FILHO, 2017, p. 203) explica que isso se deu porque os novos Estados independentes adotaram um sistema jurídico moderno único e universal, com constituições muito semelhantes às europeias que sistematicamente negavam direitos coletivos aos povos indígenas.

Em 1850, o Estado brasileiro revoga as leis portuguesas que tratavam da questão indígena, e novas leis foram criadas. O ideal de integração não fora abandonado, mas alguns direitos sobre as terras que os ocupavam foram dados aos indígenas. Por outro lado, a Constituição Republicana de 1891 é omissa em relação aos povos indígenas (SOUZA FILHO, 2012, p. 88). 
As terras indígenas eram consideradas devolutas ${ }^{1}$ desde o século XVII, portanto, tidas como indisponíveis. Mas, explica Marés (SOUZA FILHO, 2012, p. 134): “apesar disto, os Estados não vacilaram em titular terras indígenas, com tanto maior facilidade quanto mais distantes estivessem dos centros de poder". As terras pertencentes às comunidades indígenas foram sistematicamente retiradas de seus povos e estes, sem suas terras, eram obrigados ou a fugir ou a integrar-se à sociedade como trabalhadores.

Passados vinte anos do governo republicano, nada foi feito quanto à questão indígena, como aponta Ribeiro (2017, p. 119). O autor afirma que é somente em 1910 que é fundado o Serviço de Proteção aos Índios e Localização dos Trabalhadores Nacionais (SPILTN), por meio do Decreto $n^{\circ}$ 8.072. A criação se dá em um contexto temporal em que largas faixas do território nacional estavam interditadas; faixas que ligavam importantes cidades do país encontravam-se assim graças às atividades econômicas que levaram a lutas sangrentas e até ao extermínio de tribos inteiras.

Posteriormente, o SPILTN torna-se Serviço de Proteção ao Índio por meio da Lei n. 3.454. É importante notar que o SPI é criado atrelado à Localização de Trabalhadores Nacionais, porque, como aponta Marés (SOUZA FILHO, p. 92, 2018), o objetivo era tornar os indígenas trabalhadores e, portanto, integrados.

Darcy Ribeiro (2017, p. 119) explica que a criação do SPI se dá após forte movimento na sociedade que exigia do Governo Federal uma atitude quanto aos problemas existentes entre colonos e povos indígenas. Os indígenas eram "estipendiados por sociedades colonizadoras e pelos cofres públicos, para expulsá-los das terras em que sempre viveram e que haviam sido destinadas a imigrantes alemães e italianos". A imagem dos povos indígenas que se vendia na sociedade era a romantizada, uma ideia do indígena que aguarda salvação do Estado.

Com a criação do SPI, o Estado toma para si a questão indígena, retirando da Igreja essa responsabilidade. No entanto, ainda há a expectativa de integração dos povos indígenas, visando o ideal da aculturação. A partir de 1950, o SPI passa a ruir, iniciando um processo de decadência administrativa fruto de corrupção, uso indevido de terras

\footnotetext{
1 “aquelas que não são, nem nunca foram legitimamente patrimoniadas” (SOUZA FILHO, 2012, p. 134).
} 
indígenas e inclusive venda de atestados de inexistência de índios, o que legitimava o extermínio deles, uma vez que, legalmente falando, não existiam (SOUZA FILHO, 2012, p. 89).

Entre 1951 e 1964, o país vive uma grande publicização da corrupção. Em 1960, denúncias de irregularidades administrativas no SPI foram publicadas no jornal Correio da Manhã, de modo que, em 1963, a Câmara dos Deputados criou uma Comissão Parlamentar de Inquérito (CPI) para investigar o caso. A partir das informações colhidas por essa CPI, foi criada uma Comissão de Inquérito em 1967 a pedidos do Ministro do Interior (MORAES, 2015, p. 5).

As investigações realizadas pela Comissão de Inquérito resultaram em um relatório que possui quase cinco mil folhas e ficou conhecido como relatório Figueiredo, uma vez que seu relator foi Jáder Figueiredo Correia. A partir dessas informações foi possível entender como se acobertavam as violências e corrupções cometidas pelos funcionários do SPI.

Moraes (2015, p. 7) explica que foram muitas as irregularidades cometidas por funcionários do SPI; visava-se a venda do patrimônio dos povos indígenas e isso se dava por meio de troca de favores e vantagens indevidas. Comumente, além do esbulho das terras, havia a venda irregular de rebanhos pertencentes a comunidades indígenas; relatase que eram vendidos por preços três vezes menores do que o normal.

O total descaso por parte do Estado brasileiro para com os povos indígenas era evidente, eram tratados como seres não humanos. Moraes (2015, p. 12) ressalta que tais relatos são importantes, tendo em vista que permitem entender, minimamente, o que se passou com os povos indígenas entre 1910 e 1967. O autor destaca que "o poder econômico prevaleceu sobre a dignidade das populações indígenas [...]”. O órgão que deveria zelar e cuidar das populações indígenas deixa seu ideal de lado e sucumbe aos interesses econômicos.

Dados os já mencionados escândalos, em 1967 é criada a Fundação Nacional do Índio - FUNAI e o SPI é extinto. Em 1973 é criado o Estatuto do Índio que, em seu artigo primeiro, dispõe: “Esta Lei regula a situação jurídica dos índios ou silvícolas e das 
comunidades indígenas, com o propósito de preservar a sua cultura e integrá-los, progressiva e harmoniosamente, à comunhão nacional” (BRASIL, 1973, art. 1., grifo nosso). Portanto, a recém-criada FUNAI mantém o mesmo objetivo do órgão anterior: integrar os indígenas à sociedade. Marés (SOUZA FILHO, 2018, p. 92) aponta que tal integração se dá por meio do trabalho.

A integração por meio do trabalho é o motivo pelo qual a Organização Internacional do Trabalho foi o primeiro organismo internacional a tratar dos povos indígenas. Isso se deu por meio da Convenção n. 107, de 1957, que em sua ementa dispõe “Concernente à proteção e integração das populações indígenas e outras populações tribais e semitribais de países independentes" (grifo nosso). A Convenção possuía, assim como o Estatuto do Índio no Brasil, um caráter assimilacionista por meio do trabalho.

A terra indígena é finalmente entendida como categoria jurídica do Direito Brasileiro somente em 1934 quando a atual Constituição reconhece o direito à posse da terra indígena em seu artigo 129. A Constituição de 1946 mantém o status constitucional da terra indígena e a Constituição de 1967 mantém o tratamento à terra indígena trazido na Constituição anterior, somente complementando que a terra indígena está entre os bens da União.

Contudo, até a segunda metade do século XX, as políticas do Estados Nacionais, que encontravam assento no caráter integracionista presente na Convenção n. 107 da OIT, reconheciam os direitos dos povos de forma transitória. Entendiam que o direito à terra perduraria somente até a integração por meio do trabalho, como aponta Marés (SOUZA FILHO, 2018, p. 94), que conclui que existia uma ideologia que forçava o não reconhecimento do caráter permanente das comunidades indígenas e isso facilitava a integração.

Portanto, faltava um último detalhe: proclamar que o direito à terra é originário, 0 que vem a acontecer com a Constituição de 1988 (SOUZA FILHO, 2012, p. 128-129). Assim, na segunda metade do século XX, há “um renascer dos povos indígenas", consequência de um esforço dos povos que, apesar das diferenças entres etnias, se organizaram e reivindicaram seus direitos por meio de muitas lutas (SOUZA FILHO, 2017, p. 204). 
Em 1988, após o fim do regime militar, uma nova Constituição está promulgada e dedica um capítulo aos povos indígenas. Os direitos ali assinalados significaram uma quebra de paradigma na relação entre o Estado e os indígenas. A Constituição garantiu àqueles o direito de permanecer como indígena (SOUZA FILHO, 2012, p. 91).

A Constituição da República Federativa do Brasil define que as terras indígenas demarcadas são propriedade da União e visa preservá-las criando uma propriedade vinculada e reservada, de modo a garantir o direito dos indígenas sobre elas. Por isso, são terras inalienáveis, imprescritíveis e indisponíveis (SILVA, 2011, p. 859).

José Afonso da Silva (2018, p. 22) aponta que a Constituição de 1988 abandona a tese da integração ao reconhecer organização social, línguas, tradições e costumes. Do texto constitucional nota-se que "os direitos dos índios às terras por eles tradicionalmente ocupadas preexistem ao próprio reconhecimento constitucional." Esses direitos, aponta o autor, coexistem com o próprio ser das comunidades indígenas e o sistema constitucional desde a Constituição de 1934, que acolheu como forma de direito constitucional fundamental.

Quanto à demarcação de terra indígena, Marés (SOUZA FILHO, 2012, p. 148) explica que "somente é necessária para sua própria proteção física, mas não se pode deixar de protegê-las juridicamente ainda que não haja demarcação.” A demarcação é um ato secundário; primeiro é necessário que as terras sejam tradicionalmente ocupadas pelos povos indígenas. Ao demarcar uma terra indígena, faz-se necessário levar em conta o sentimento do povo que a habita e não somente a ideia de patrimônio do direito moderno.

Marés (SOUZA FILHO, 2012, p. 150) assevera que a omissão do Estado brasileiro é evidente. O Estatuto do Índio de 1973 determinava que todas as terras indígenas deveriam ser demarcadas em cinco anos, ou seja, 1978. Em 1988, o Ato das Disposições Constitucionais Transitórias (ADCT), art. 67, repete o mesmo prazo: cinco anos para demarcação das terras indígenas. Contudo, o decreto que regulamenta as demarcações somente foi emitido em 1996 - Decreto 1.775, e ainda hoje as demarcações não foram concluídas. 
A Convenção n. 107 é rediscutida com a participação dos povos indígenas e uma nova Convenção é aprovada em 1989: a Convenção n. 169 que rompe com o integracionismo (SOUZA FILHO, 2017, p. 211). Nesse mesmo sentido, estão a Declaração das Nações Unidas sobre os Direitos dos Povos Indígenas, aprovada em 2007, e a Declaração Americana sobre os Direitos dos Povos Indígenas, em 2016 (SOUZA FILHO, 2018, p. 93).

Contudo, dados do Conselho Indigenista Missionário (CIMI, 2020, p. 53) apontam que das 1.298 terras indígenas existentes no Brasil apenas 408 estão devidamente registradas, outras 40 são reservas e outras seis são de propriedade da própria comunidade; assim, o restante de 829 terras indígenas encontra-se com pendência administrativa. O Cimi aponta que no ano de 2019 nenhuma terra indígena foi demarcada e a situação se torna pior quando 27 procedimentos de regularização de terras indígenas que estavam aguardando homologação presidencial são devolvidos ao Ministério da Justiça para adequação ao marco temporal.

A tese do marco temporal faz parte do acórdão da Petição n. 3.388/RR que tramitou no Supremo Tribunal Federal questionando a demarcação da Terra Indígena Raposa Serra do Sol. Não obstante não tivesse relação com o caso em questão, o Supremo criou 19 condicionantes aos direitos constitucionais dos povos indígenas e a tese do marco temporal, que implica dizer que um povo só teria direito à demarcação se ocupasse a terra de forma tradicional na data da promulgação da Constituição.

\section{O marco temporal no Supremo Tribunal Federal e demais normativas}

A Terra Indígena Raposa Serra do Sol, segundo dados compilados pelo Instituto Socioambiental (2020), é habitada por membros das etnias Macuxi, Ingarikó, Patamona, Taurepang e Wapichana. Marés (SOUZA FILHO, 2013, p. 35) aponta que esta TI foi visitada por Marechal Cândido Rondon no começo do século XX ao demarcar as fronteiras do Brasil na Amazônia. Em 1980, os povos residentes passam a denunciar invasão do território para criação de gado, mas o processo demarcatório somente foi finalizado em 2005 . 
Os interessados na não demarcação - como o Estado de Roraima, arrozeiros e Senadores de Roraima - ajuizaram a Ação Popular n ${ }^{\circ} 9994200000014-7$ na $1^{\circ}$ Vara da Seção Judiciária de Roraima visando anular as normativas que demarcara a TI em questão. O Ministério Público Federal entendendo que se tratava de usurpação da competência do Supremo Tribunal Federal ajuizou reclamação² perante o Supremo, que deu procedência ao pedido e determinou sua própria competência para julgar o caso.

Assim, o processo passou a ser julgado pelo Supremo Tribunal Federal e recebeu o nome/número de Petição 3.388/RR. Foi distribuído em 20 de abril de 2005 e teve como relator o então Ministro Carlos Britto, contudo, ao longo do processo alguns Ministros faleceram ou se aposentaram, o que mudou a composição do Tribunal. Após o julgamento em 2009 foram ajuizados Embargos de Declaração e o trânsito em julgado se deu somente em 11 e setembro de $2018^{3}$.

Visando entender como se deu a decisão dos Ministros, vamos apresentar trechos dos votos que tratam do marco temporal. Não apresentaremos o voto do Ministro Joaquim Barbosa porque este se posiciona contrário a discutir temas alheios aos pedidos das partes, portanto, as tais condicionantes e o marco temporal.

O Ministro relator Carlos Ayres Brito é o primeiro a votar e trata do marco temporal. Ao realizar uma análise do corpo normativo da Constituição, em específico de seu art. $231^{4}$, o Ministro entende ser possível concluir que a Constituição teria trabalhado com data certa "como insubstituível referencial para o reconhecimento, aos índios, dos direitos sobre as terras que tradicionalmente ocupam", citando a Constituição e aponta:

A terra que tradicionalmente ocupam, atente-se, e não aquelas que venham a ocupar. Tampouco as terras já ocupadas em outras épocas,

\footnotetext{
${ }^{2}$ BRASIL. Supremo Tribunal Federal. Reclamação 2.833-0. Ementa: Reclamação. Usurpação da competência. [...]. Min. Relator Carlos Ayres Britto, 14 abr. 2005. Disponível em: https://jurisprudencia.stf.jus.br/pages/search/sjurg5234/false. Acesso em: 17 nov. 2020.

3 Informação disponível no consultor processual público do Supremo Tribunal Federal. Disponível em: http://portal.stf.jus.br/processos/detalhe.asp?incidente=4548671. Acesso em 19 nov. 2020.

4 São reconhecidos aos índios sua organização social, costumes, línguas, crenças e tradições, e os direitos originários sobre as terras que tradicionalmente ocupam, competindo à União demarcá-las, proteger e fazer respeitar todos os seus bens.
} 
mas sem continuidade suficiente para alcançar o marco objetivo do dia 5 de outubro de 1988. (BRASIL, 2009, p. 295, grifo do autor)

Esse é o conceito de marco temporal. O Ministro ainda justifica afirmando que esse marco serviria para “colocar uma pá de cal nas intermináveis discussões sobre qualquer outra referência temporal de ocupação de área indígena”, e despreza outra Constituição como marco. O Ministro, então, vota favorável à manutenção da Portaria e, portanto, da demarcação, afirmando que as etnias residentes na TI em questão já estavam lá na data de cinco de outubro de 1988 (BRASIL, 2009, p. 336).

O próximo a votar é o Ministro Menezes Direito que destaca primeiramente a “sensibilidade social” do Ministro que votou anteriormente (BRASIL, 2009, p. 367). Mais adiante, expressa seu entendimento afirmando que o caput do art. 231 possui dois elementos principais: o advérbio "tradicionalmente" e o verbo “ocupam”. Este último se referindo às terras ocupadas pelos indígenas, "não terras que ocuparam em tempos idos e não mais ocupam; não são terras que ocupavam até data certa e não ocupam mais.". 0 Ministro afirmar ser possível concluir, então, que se refere às terras ocupadas pelos indígenas quando da promulgação da Constituição (BRASIL, 2009, p. 378).

O Ministro Menezes Direito defende que não se utilize mais a teoria do indigenato 5 , mas sim a teoria que ele chama de fato indígena que, em seu entendimento, seria a presença de indígenas na terra na data da promulgação da Constituição (BRASIL, 2009, p. 383). Afirma, ainda, que a ciência oferece meios para identificação da presença indígena ou de fato indígena, como o Ministro chama. Defende que o $\S 6^{\circ 6}$ do art. 231 somente tem aplicação se na data de 05 de outubro de 1988 os indígenas estivessem no local (BRASIL, 2009, p. 384).

\footnotetext{
5 Segundo José Afonso da Silva (2011, p. 861): "O indigenato é a fonte primária e congênita da posse territorial; é um direito congênito, enquanto ocupação é um título adquirido."

${ }^{6}$ São nulos e extintos, não produzindo efeitos jurídicos, os atos que tenham por objeto a ocupação, o domínio e a posse das terras a que se refere este artigo, ou a exploração das riquezas naturais do solo, dos rios e dos lagos nelas existentes, ressalvado relevante interesse público da União, segundo o que dispuser lei complementar, não gerando a nulidade e a extinção de direito à indenização ou a ações contra a União, salvo, na forma da lei, quanto às benfeitorias derivadas da ocupação de boa fé.
} 
Ao final do seu voto, o Ministro entende que da apreciação do caso seria possível perceber que os argumentos das partes são extensíveis e aplicáveis aos demais conflitos. Assim, julga parcialmente procedente o pedido afirmando que certas condições devem ser impostas e, então, cria 18 condicionantes que supostamente deveriam ser aplicadas às demarcações. Por força do objeto do trabalho, não trataremos das condicionantes (BRASIL, 2009, p. 416).

A Ministra Carmem Lúcia vota pela improcedência do pedido e, portanto, manutenção da demarcação. A respeito das condicionantes, a Ministra não se posiciona. Ela é questionada pelo Ministro Gilmar Mendes, então presidente, a respeito e afirma que não se opõe; ainda, é questionada a respeito da vedação da ampliação da demarcação e se diz favorável à vedação (BRASIL, 2009, p. 480-481).

O Ministro Ricardo Lewandowski (BRASIL, 2009, p. 509) vota pela improcedência parcial do pedido e adere integralmente às 18 propostas enunciadas pelo Ministro Menezes Direito. Ainda, afirma ser contrário à ampliação de terra já demarcada, porque a Constituição supostamente a vedaria já que determinou prazo certo para as demarcações, indicando seu posicionamento acerca do marco temporal.

O Ministro Eros Grau profere seu voto pela improcedência do pedido e favorável às condicionantes pensadas pelo Ministro Menezes Direito. Em seu voto, afirma que a Constituição de 1988 reconheceu aos indígenas seus direitos originários sobre as terras que ocupavam tradicionalmente na data de sua promulgação (BRASIL, 2009, p. 514). Em outro momento, o Ministro afirma que não há dúvidas de que as cinco etnias indígenas que vivem na TI Raposa Serra do Sol lá estavam na data da promulgação da Constituição, dando a entender que o Ministro reconhece o marco temporal como um requisito e já o aplica no caso em questão (BRASIL, 2009, p. 517).

O então Ministro Carlos Peluzo (BRASIL, 2009, p. 535), já no início de seu voto, elogia as condicionantes criadas pelo Ministro Menezes Direito e afirma seu entendimento de que a posse jurídica na data de início da vigência da Constituição corresponde, praticamente, à posse civil. Ainda, afirma que a postura da Corte nesse 
julgamento em questão traçaria diretrizes para todas as ações de mesmo tema (BRASIL, 2009, p. 573).

O Ministro, então, afirma que a Constituição estabeleceu um marco para proteção das terras indígenas ocupadas na data de sua promulgação e que a demarcação contínua é contraposta a essa ideia. Ele defende que se deve verificar o lugar que os indígenas de fato ocupam e afirma que isso não é feito para evitar esforços e não atender a tal mandamento, é se harmonizar com "diversas sinalizações internacionais de cunho separatista". Mas não menciona quais são essas tais diversas sinalizações (BRASIL, 2009, p. 674). Por fim, votou pela procedência do pedido e, portanto, anulação do ato demarcatório (BRASIL, 2009, p. 692).

O Ministro Marco Aurélio, em seu voto, se mostra favorável ao marco temporal e afirma que "A atual Carta não assegura aos indígenas o retorno às terras que outrora ocuparam, seja qual for a situação jurídica atual e o tempo decorrido desde que as deixaram" (BRASIL, 2009, p. 686). Vota, então, favorável à procedência do pedido, diferentemente dos demais Ministros, sendo favorável à anulação da Portaria do Ministério da Justiça e do Decreto que homologou a demarcação e das condicionantes criadas pelo Ministro Menezes Direito (BRASIL, 2009, p. 692).

O Ministro Celso de Mello, em seu voto, afirma que seria necessário ter em mente que o art. 231 da Constituição Federal teria estabelecido um marco bastante preciso a respeito da ocupação indígena que seria o dia de sua promulgação. Desse modo, a proteção prevista na Constituição somente se aplica às terras nessa situação. Por outro lado, rechaça a ideia de que a posse indígena é o mesmo que a posse civil (BRASIL, 2009, p. 721), e vota pela improcedência do pedido (BRASIL, 2009, p. 736).

O Ministro Gilmar Mendes (BRASIL, 2009, p. 832) vota pela procedência parcial da ação, afirmando ser favorável às condicionantes apresentadas pelo Ministro Menezes Direito e adiciona mais uma: participação efetiva dos Estados e Municípios no procedimento administrativo de demarcação de Tls.

Os Ministros, então, passam a discutir as condicionantes. Com exceção do Ministro Joaquim Barbosa, que expressa ser contrário a todas, os demais concordam sugerindo 
algumas modificações e as aprovam (BRASIL, 2009, p. 862). A pedido do Ministro Carlos Britto, as condicionantes vão para a parte dispositiva da decisão (BRASIL, 2009, p. 528).

Assim, quase todos os Ministros votaram pela manutenção da demarcação, ou seja, se manifestaram contrários aos pedidos daqueles que ingressaram com a ação. Contudo, discutem a respeito do marco temporal e das condicionantes criadas por um dos Ministros que nada tem a ver com os pedidos feitos pelas partes. Os votos dos Ministros Carlos Peluzo e Marco Aurélio são dissidentes em relação ao pedido, mas concordam com os demais ministros no que diz respeito às condicionantes e ao marco temporal.

O julgamento se deu em 2009 e em 16 de julho de 2012, a Advocacia Geral da União (AGU) editou a Portaria n. $303^{7}$ que determinou que a Administração Pública Federal direta e indireta aplicasse as condicionantes e o marco temporal apresentados no julgamento do caso Raposa Serra do Sol (PET 3.388/RR). Essa Portaria foi suspensa pela Portaria n. $308^{8}$ que determinou que a anterior passaria a vigorar no dia 24 de setembro de 2012.

Nesse meio tempo, houve interposição de Embargos de Declaração na Pet. 3.388. Assim, uma nova portaria, Portaria $415^{9}$, determinou que a vigência da Portaria 303 se daria um dia após a publicação do acórdão dos Embargos de Declaração da PET 3.388/RR.

A interposição dos Embargos se deu visando explicitar o caráter não vinculante da decisão e foi julgado em 23 de outubro de 2013. Nesse meio tempo, o antigo relator se aposentou e o relator se tornou o Ministro Luís Roberto Barroso, o qual afirmou que:

\footnotetext{
7 ADVOCACIA- GERAL DA UNIÃO. Portaria $n^{\circ}$ 303, de 16 de julho de 2012. Dispõe sobre as salvaguardas institucionais às terras indígenas conforme entendimento fixado pelo Supremo Tribunal Federal na Petição $3.388 \quad$ RR. Brasília: [AGU], 2012. Disponível em: https://antigo.agu.gov.br/page/atos/detalhe/idato/596939. Acesso em: 26 nov. 2020.

${ }^{8}$ ADVOCACIA- GERAL DA UNIÃO. Portaria $\mathbf{n}^{\circ} 308$, de 25 de julho de 2012. Altera o disposto no art. $6^{\circ}$ da portaria $\mathrm{n}^{\circ}$ 303, de 16 de julho de 2012. Brasília: [AGU], 2012. Disponível em: https://antigo.agu.gov.br/page/atos/detalhe/idato/606114. Acesso em: 26 nov. 2020.

9 ADVOCACIA- GERAL DA UNIÃO. Portaria $\mathrm{n}^{\circ} 415$, de 17 de setembro de 2012. Altera o disposto no art. $6^{\circ}$ da Portaria $\mathrm{n}^{\circ} 303$, de 16 de julho de 2012 e revoga a Portaria ${ }^{\circ} 308$ de 25 de julho de 2012. Brasília: [AGU], 2012.Disponível em: https://antigo.agu.gov.br/page/atos/detalhe/idato/657974. Acesso em: 26 nov. 2020.
} 
A decisão proferida em ação popular é desprovida de força vinculante, em sentido técnico. Nesses termos, os fundamentos adotados pela Corte não se estendem, de forma automática, a outros processos em que se discuta matéria similar. Sem prejuízo disso, o acórdão embargado ostenta a força moral e persuasiva de uma decisão da mais alta Corte do País, do que decorre um elevado ônus argumentativo nos casos em se cogite da superação de suas razões. (BRASIL, 2013, p. 91, grifo nosso)

Ainda no julgamento dos Embargos, o Ministro Joaquim Barbosa expressa seu entendimento de que o STF "extrapolou excessivamente abstratos e completamente alheio ao que foi proposto originalmente. O Tribunal agiu como um verdadeiro legislador". E vota para que as condicionantes sejam retiradas do dispositivo. Assim, ficou explicitado que a decisão não possui caráter vinculante, contudo, as condicionantes e o marco temporal foram mantidos no dispositivo da decisão.

Após a publicação do acórdão era para a Portaria 303 ter vigência, conforme explicitado anteriormente, contudo em 2014, uma nova portaria, Portaria n. $27^{10}$, determinou à Consultoria-Geral da União e à Secretária-Geral de Contencioso a análise de adequação da Portaria n. 303/12.

Eloy Terena (AMADO, 2020) explica que "diversos órgãos da Administração Pública (FUNAI, AGU, PFE/FUNAI, CONJUR/MJ/CGU/AGU) se envolveram em uma controvérsia sobre a vigência e eficácia da Portaria em questão (Portaria n. 303)”. Então, em 2016, o Advogado-Geral da União, por meio do Despacho n. $358^{11}$, estabeleceu que a Portaria 303 ficaria com seus efeitos suspensos até a apresentação do parecer.

No STF, a tese do marco temporal, mesmo após a manifestação afirmando que a decisão da Pet. 3.388/ RR não possuía efeito vinculante, foi aplicada pela a $2^{\circ}$ Turma do STF em três processos no ano de 2014: Recurso em Mandado de Segurança (RMS) n. $29.087^{12}$ que discute o caso da Terra Indígena Guyraoka, onde vive a etnia Guarani Kaiowá

\footnotetext{
${ }^{10}$ ADVOCACIA-GERAL DA UNIÃO. Portaria nº 27, de 7 de fevereiro de 2014. Determina à Consultoria-Geral da União - CGU e à Secretária-geral de Contencioso - SGCT a análise da adequação do conteúdo da Portaria AGU $\mathrm{n}^{\circ}$ 303, de 16 de julho de 2012. Brasília: [AGU], 2012. Disponível em: https://antigo.agu.gov.br/page/atos/detalhe/idato/1494186. Acesso em: 26 nov. 2020.

${ }^{11}$ Não foi possível encontrar o Despacho para referenciá-lo, tal informação, além de ser mencionada por Eloy Terena, encontra-se no próprio texto do Parecer 001/17.

12 BRASIL. Supremo Tribunal Federal. Recurso Ordinário em Mandado de Segurança n. 29.087. Ementa:
} 
no Mato Grosso do Sul; Recurso em Mandado de Segurança (RMS) 29.542/DF ${ }^{13}$ que trata da Terra indígena Porquinhos dos Canela - Apãnjekra, onde reside o povo Canela Apanyekrá; e Agravo em Recurso Extraordinário com Agravo n. $803.462^{14}$ que trata da Terra Indígena Limão Verde, onde vive o povo Terena.

Já no ano de 2017 é emitido o Parecer 001/2017 15 da AGU elaborado por André Rufino do Vale, defendendo a legitimidade da Portaria 303/12 e determinado sua aplicação por toda administração pública direta e indireta. Contudo, em fevereiro de 2019, foi reconhecida a repercussão geral do recurso extraordinário (RE) n. 1.017.365/SC ${ }^{16}$ que busca estabelecer um estatuto jurídico constitucional dos direitos dos povos indígenas à terra. O processo originário trata da comunidade indígena Xokleng que visa manter o reconhecimento de seu território. A comunidade, por meio de uma tutela provisória na Ação Cível Originária n. $1.100^{17}$, conseguiu, em fevereiro de 2020, a suspensão dos efeitos da Portaria n. 001/17 da AGU até o julgamento do recurso extraordinário.

A respeito do recurso extraordinário n. 1.017.365/SC, cabe tecer alguns comentários dada a sua íntima relação com o objeto de estudo do trabalho. Como foi possível notar, a discussão acerca da extensão dos direitos dos povos indígenas é intensa nos tribunais, não obstante a nitidez do disposto na Constituição. Nesse sentido, o RE

Demarcação De Terras Indígenas. O Marco Referencial Da Ocupação É A Promulgação Da Constituição Federal De 1988. [...] Relator Min. Ricardo Lewandowski. Brasília: [STF], 16 set. 2014. Disponível em: https://jurisprudencia.stf.jus.br/pages/search/sjur280522/false. Acesso em: 19 nov. 2020.

13 BRASIL. Supremo Tribunal Federal (2 Turma). Recurso Ordinário em Mandado de Segurança. 29.542. Ementa: Recurso Ordinário Em Mandado De Segurança. Terra Indígena Demarcada Na Década De 1970. [...]. Relator Min. Carmem Lúcia. Brasília: [STF], 30 set. 2014. Disponível em: http://portal.stf.jus.br/processos/detalhe.asp?incidente=3979135. Acesso em 27 nov. 2020.

14 BRASIL. Supremo Tribunal Federal (2 $2^{\circ}$ Turma). Agravo Em Recurso Extraordinário. 803.462. Ementa: Constitucional E Administrativo. Terra Indígena “Limão Verde”. Marco Temporal. [...]. Relator Min. Teori Zavascki. Brasília: [STF], 09 dez. $2014 . \quad$ Disponível em: http://portal.stf.jus.br/processos/detalhe.asp?incidente=4548671. Acesso em 27 nov. 2020.

${ }^{15}$ ADVOCACIA GERAL DA UNIÃO. Parecer 001/2017. O Supremo Tribunal Federal, no acórdão proferido no julgamento da PET 3.388/RR. Brasília: [AGU], 2017. Disponível em : https://antigo.agu.gov.br/page/atos/detalhe/idato/1552758. Acesso em 27 nov. 2020.

16 BRASIL. Supremo Tribunal Federal. Recurso Extraordinário. 1.017.365. Ementa: Constitucional. Administrativo. Posse Indígena. Terra Ocupada Tradicionalmente Por Comunidade Indígena. Possibilidades Hermenêuticas Do Artigo 231 Da Constituição Da República. [...]. Relator Min. Edson Fachin, Brasília: $\quad$ [STF], 21 fev. 2020 Disponível em: http://portal.stf.jus.br/processos/detalhe.asp?incidente=5109720. Acesso em 27 nov. 2020.

${ }_{17}$ BRASIL. Supremo Tribunal Federal. Tutela Provisória Incidental na Ação Cível Originária. 1.100. Relator Min. Edson Fachin, Brasília: [STF], 20 fev. 2020. Disponível em: http://portal.stf.jus.br/processos/detalhe.asp?incidente=11818. Acesso em: 27 nov. 2020. 
mencionado visa dar um fim às discussões ao estabelecer um estatuto jurídico constitucional dos povos, dada a reconhecida repercussão geral, a decisão será aplicável aos demais casos.

O RE n. 1.017.365 é originário de Santa Catarina e tem como recorrente a Funai e como recorrido a Fundação do Meio Ambiente do Estado, isso porque, como alega o recorrido, os indígenas da etnia Xokleng estariam vivendo em parte da Reserva Biológica dos Sassafrás e, portanto, não se trataria de terra indígena. A primeira instância decidiu que deveria haver reintegração de posse e os indígenas deveriam ser retirados da área. $\mathrm{A}$ segunda instância confirmou a decisão e a Funai recorreu ao STF por meio de recurso extraordinário, dada a importância constitucional do tema. Cabe ressaltar que o processo demarcatório das terras do povo Xokleng na região na discussão está em curso.

A Funai alega que há ocupação tradicional indígena nos moldes do art. 231 da Constituição e, por isso, não pode ser reconhecido o direito de posse do recorrido Fundação do Meio Ambiente. Eloy Terena (AMADO, 2020) explica que o recurso extraordinário mencionado é tido como emblemático para os povos indígenas e, por isso, muitas organizações solicitaram participação no processo como: Articulação dos Povos Indígenas no Brasil (Apib), Conselho do Povo Terena, Aty Guasu Guarani Kaiowá, Coordenação das Organizações Indígenas da Amazônia Brasileira (Coiab), Cimi, entre outros.

Visando facilitar o entendimento do leitor acerca do marco temporal e os julgados e normativas que dizem respeito, elaboramos uma linha do tempo:

Figura 1 - Linha do tempo marco temporal

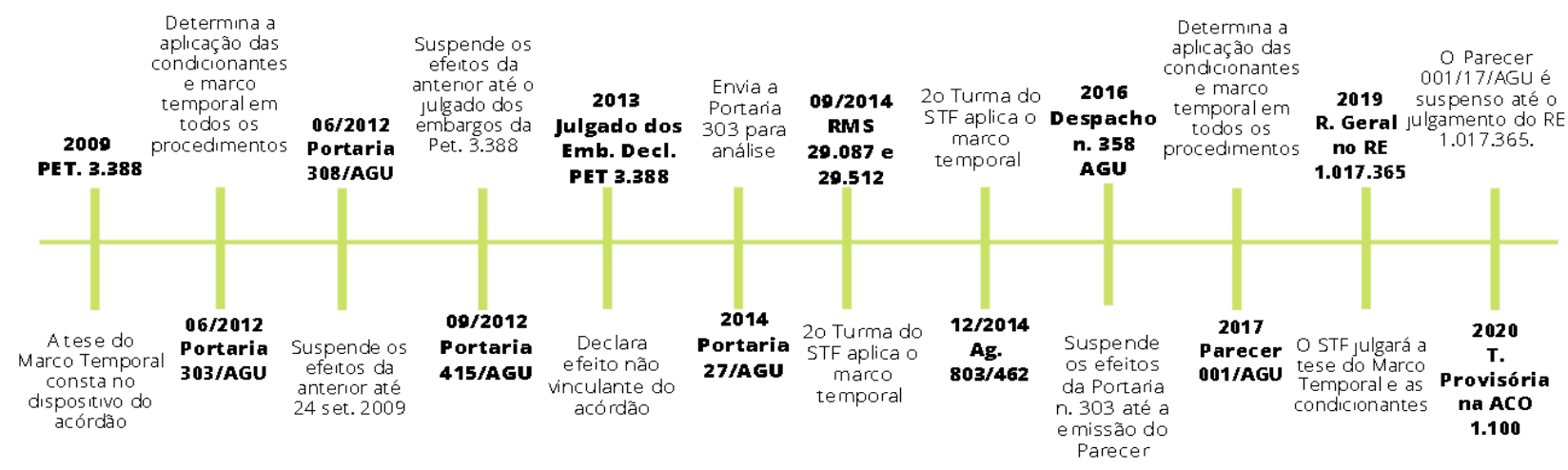


Fonte: criada no site Canva pelos autores, 2020.

Eloy Terena (2020) explica que há grande resistência por parte dos povos indígenas acerca do marco temporal e, em 2017, a Articulação dos Povos Indígenas (Apib) lançou a campanha: "nossa história não começa em 88”. Assim, após anos de lutas, os povos indígenas viram seus direitos reconhecidos na Constituição de 1988, que reconheceu não somente o direito à terra, mas o direito de ser indígena. Longos anos de violência expulsaram os povos de seus territórios originários facilitando a perda da cultura e dos costumes. A Constituição de 1988 representa, assim, uma quebra dos paradigmas ao reconhecer o direito de ser e permanecer sendo indígena. Contudo, o marco temporal se mostra contrário a esse espírito, já que limita qual povo tem ou não direito a sua terra, desconsiderando os processos que afastaram os povos.

\section{O marco temporal como ruptura no reconhecimento dos direitos dos povos}

\section{indígenas}

A Articulação dos Povos Indígenas do Brasil (APIB, 2017), logo após a aprovação do Parecer 001/17, publicou em seu site oficial sua manifestação contrária à tese do marco temporal explicando que, na prática, a tese vai legitimar e legalizar as violências cometidas contra os povos indígenas até 04 de outubro de 1988, "uma realidade de confinamento em reservas diminutas, remoções forçadas em massa, tortura, assassinatos e até a criação de prisões." De forma que, como aponta a Apib, aprovar essa tese seria anistiar os crimes cometidos contra os povos e "dizer aos que hoje seguem invadindo suas terras (dos povos indígenas) que a grilagem, a expulsão e o extermínio de indígenas é uma prática vantajosa, pois premiada pelo Estado brasileiro". E, ao contrário do que apontado pelos Ministros, a Apib entende a tese somente fomentará a violência no campo, que já é grande.

Marés (SOUZA FILHO, p. 36, 2013) é categórico ao afirmar que as condicionantes ou "salvaguardas" criadas pelos Ministro Menezes Direito são, na realidade, restrições e obstáculos ao reconhecimento de um direito expresso na Constituição. De modo que no 
julgamento da Pet. 3.388, o Supremo Tribunal Federal "expressou seus preconceitos e uma ideologia anti-indígena”. Em seus respectivos pedidos, nenhuma das partes solicitou nada a respeito do marco temporal e nem a respeito das tais condicionantes, portanto, não houve pedido nesse sentido; além disso, o autor questiona como uma simples decisão pode ser aplicada a todas as demarcações como pretendeu a $2^{\circ}$ Turma do STF e a Advocacia-Geral da União por meio de sua portaria 303/12 e, posteriormente, Parecer $001 / 17$.

O Parecer 001/17 encontra-se suspenso, como já mencionado, por força de uma liminar, já que seu objeto será tratado em sede de Recurso Extraordinário. O Parecer somente buscou justificar a Portaria 303/12. Marés (SOUZA FILHO, 2013, p. 40) aponta três graves erros relacionados à Portaria: 1) as condicionantes não podem possuir caráter geral como uma lei; isso somente poderia se dar por meio de Súmula Vinculante; 2) falta motivação; é duvidosa a competência da AGU para emanar ato com tal conteúdo e não há interesse público em condicionar os direitos dos povos indígenas; 3) a Portaria obriga todos os advogados da União, inclusive os da Funai, a agir contra os povos indígenas ao aplicar as condicionantes e o marco temporal.

Para José Afonso da Silva (2018, p. 25), a ideia do marco temporal é contrária à Constituição, sendo, portanto, inconstitucional, pois em nenhum momento o texto constitucional faz menção a essa data. O autor explica que a Constituição, no art. 231, $\S 1^{018}$, utiliza a palavra "reconhecidos" para explicitar que os direitos dos povos indígenas já existiam antes mesmo da promulgação da Constituição Se tivesse sido utilizada a palavra "conferidos", talvez coubesse discussão, mas não foi o caso. Esse reconhecimento não é transitório, como outrora em que se reconhecia o direito à terra e esperava-se a integração do indígena; trata-se de um reconhecimento permanente.

Para Silva (2018, p. 26), a Constituição de 1988 é um último elo de reconhecimento jurídico-constitucional de uma continuidade histórica de direitos originários dos povos indígenas sobre suas terras. O marco temporal trabalha com data certa, então, diz o

\footnotetext{
${ }^{18}$ São terras tradicionalmente ocupadas pelos índios as por eles habitadas em caráter permanente, as utilizadas para suas atividades produtivas, as imprescindíveis à preservação dos recursos ambientais necessários ao seu bem-estar e as necessárias a sua reprodução física e cultural, segundo seus usos, costumes e tradições.
} 
autor, que trabalhe com data da primeira legislação que reconheceu o direito dos povos indígenas às suas terras: a Carta Régia de 1611, promulgada por Felipe III.

Conclui o autor que a Constituição de 1988 é sim importante,

[...], mas não é um marco, deslocar esse marco para ela é fazer um corte na continuidade da proteção constitucional dos direitos indígenas, deixando ao desamparo milhares de índios e suas comunidades, o que, no fundo, é um desrespeito às próprias regras e princípios constitucionais que dão proteção aos direitos indígenas. (SILVA, 2018, p. 27)

Seria, além de um corte na continuidade da proteção constitucional, um desrespeito e desconsideração com as lutas dos povos indígenas que resistem às violências e invasões dos não indígenas desde 1500. Silva (2018, p. 27) é contundente ao afirmar que a justificativa de que o marco temporal poria fim às disputas entre indígenas e fazendeiros não é verdade. Para ele, é evidente que não se buscou criar uma marco de proteção aos povos indígenas, mas sim para dar fim a conflitos, cassando os direitos dos povos indígenas, ou seja, os conflitos entre indígenas e fazendeiros devem ser resolvidos em detrimento dos direitos dos povos indígenas, desconsiderando as normas constitucionais.

José Afonso da Silva (SILVA, 2018, p. 28) aponta que a situação já calamitosa se torna ainda pior quando o Supremo Tribunal Federal surge com o termo "renitente esbulho" nos julgamentos que seguiram a Pet 3.388. Esse conceito, supostamente, serviria para averiguar se povos que não estavam em suas terras na data da promulgação da Constituição têm direito à demarcação. Ou seja, o STF admite que povos foram retirados de suas terras de forma arbitrária e, para que nesses casos haja demarcação, é necessário que o povo demonstre que ocorreu o tal renitente esbulho.

Esse termo foi cunhado pelo próprio Supremo, já que na literatura jurídica se utiliza o temo esbulho renitente e não ao contrário. O autor (SILVA, 2018, p. 28) aponta que a inversão na ordem das palavras foi proposital visando dar aos povos indígenas o ônus de provar o esbulho de suas terras. Ainda, esbulho é um termo do direito civil e 
compatível com a posse civil, não com a posse indígena que possui características únicas que fogem à organização capitalista.

Outro ponto apontado por Silva (2018, p. 29) é a exigência de que esse tal "renitente esbulho", mesmo que iniciado no passado, perdure até a data do marco temporal, forjando-se aí um marco e exigindo a manutenção do conflito para o reconhecimento do direito. Em outras palavras: se um povo indígena teve sua terra invadida antes de 05 de outubro 1988, teria que ter resistindo às violências e permanecido na terra para que seu direito fosse reconhecido. O STF, por meio do marco temporal e do renitente esbulho, ignora a violência impetrada contra os povos indígenas que em diversos momentos, como apontamos na primeira parte do texto, tiveram que fugir de seus territórios ancestrais ou foram integrados ao trabalho de forma forçada.

O autor (2018, p. 29) explica que esbulho é um termo do direito possessório, que por sua vez é um ramo do direito civil, segundo o qual o possuidor é retirado de sua posse de forma violenta pelo esbulhador. A relação dos povos indígenas com suas terras não é a mera posse civil em que a coisa serve ao senhor; é uma relação que se dá pelo indigenato de modo que qualquer ocupação em terra indígena por não indígenas não pode ser reconhecida; é o que pretende a Constituição em seu art. 231, §4 ${ }^{019}$ e também o $\S 6^{\circ}$.

Ainda, no entendimento de José Afonso da Silva (2018, p. 34), ao exigir a existência do esbulho renitente, o Supremo reconhece a existência de conflitos entre indígenas e não indígenas, mas esquece quem de fato iniciou o conflito: os usurpadores. A fonte dos conflitos é a invasão e grilagem de terras indígenas e, mesmo assim, os Ministros acreditam ser razoável que o ônus recaia sobre os povos indígenas. Para provar o esbulho é necessário que haja uma controvérsia possessória judicializada, ou seja, para demonstrar que o povo resistiu ao esbulho, é necessário que haja um processo judicial, exigindo uma atitude típica de não indígenas aos indígenas, além de ignorar que até a Constituição de 1988 os povos indígenas viviam em um regime tutelar e, portanto, não poderiam ajuizar um processo para defender seus interesses. Por fim, o autor conclui que

\footnotetext{
${ }^{19}$ As terras de que trata este artigo são inalienáveis e indisponíveis, e os direitos sobre elas, imprescritíveis.
} 
os povos indígenas retirados de suas terras têm direito de retornar, independentemente se houve esbulho, tal direito deve ser garantido pelo Poder Público.

A respeito do tempo no direito, Marés (Souza, 2018, p. 75) explica que esse é um importante agente no direito moderno que determina quando nasce e quando morre um direito, trazendo consequências patrimoniais. Trata-se de um pensamento que se expressa de forma fechada e sem lacunas fundado no direito absoluto de propriedade. Contudo, não é possível aplicar tal pensamento aos direitos coletivos ${ }^{20}$ das comunidades, uma vez que esses direitos nascem e morrem com as comunidades. Ao buscar criar um marco temporal aos direitos dos povos indígenas se aplica uma lógica dos direitos individuais e que "certamente cometerá erros e injustiças".

Ao reconhecer os direitos dos povos indígenas, o autor (SOUZA FILHO, 2018, p. 80) aponta que nem as constituições da América Latina e nem as leis regulamentaram com exatidão esses direitos; os poderes e as faculdades dos sujeitos de direito não foram nem mesmo descritos pelas leis. Isso facilita a não aplicação ou sua deturpação, especialmente nos tribunais que estão habituados a aplicar direitos individuais que possuem poderes e faculdades descritos na lei.

As comunidades indígenas já existiam antes mesmo do reconhecimento legal de sua existência, de modo que os direitos que possuem também já existiam antes mesmo de serem reconhecidos. Aponta Marés (SOUZA FILHO, 2018, p. 82): "Esses direitos precedem ao Estado e suas leis e se formam fora dele"; é por esse motivo que a Constituição utiliza a palavra originários para se referir aos direitos dos povos indígenas.

Explica o autor (SOUZA FILHO, 2018, p. 90) que dois direitos se destacam no que diz respeito aos povos e comunidades tradicionais: direito de existir e o direito à terra. $O$ primeiro implica em reconhecer os direitos dos povos em viverem segundo seus usos, costumes e tradições; é o direito de continuar sendo indígena, direito este que foi negado até a Constituição de 1988. Ao Estado não cabe mais integrá-los. O segundo direito está

\footnotetext{
${ }^{20}$ Mais informações sobre direitos coletivos nesse contexto: SOUZA FILHO, Carlos Frederico Marés. Marco temporal e direitos coletivos. In: CARNEIRO DA CUNHA, Manuela; BARBOSA, Samuel (orgs.). Direitos dos povos indígenas em disputa. São Paulo: Editora Unesp, 2018. p. 75-100.
} 
ligado à terra "se o povo existe, tem que estar em algum lugar. Se estiver em um lugar que não pode praticar sua cultura, prover sua vida como povo, está em risco, e o risco é etnocídio". Assim, conclui: "Essa relação entre existência física e lugar de estar, quer dizer, a existência da comunidade e de seu território, é uma relação que completa, ou realiza, o direito coletivo". De modo que são grupos humanos com uma relação ímpar com a terra.

Os povos indígenas, e demais povos tradicionais, não atribuem valor de troca à terra, “[...] isto é, não a consideram uma mercadoria e por isso são coletivas, sem a possibilidade ética de se desfazer dela, o equivalente a abrir mão da existência como coletividade" (SOUZA FILHO, 2018, p. 91). O pertencimento à terra e a íntima relação com natureza são contrários à formação social e econômica do capitalismo que atribui valor de mercadoria à terra, inclusive, atribuindo valor maior à terra vazia.

Os mencionados direitos à terra e à existência são intimamente ligados; a negação de um direito se estende ao outro, um povo sem sua terra, sem ter onde praticar sua cultura, corre sério risco de desaparecer e um povo cuja existência não é reconhecida, como acontecia no Brasil até 1988, corre riscos de perder suas terras, porque a sua existência é entendida como temporária (SOUZA FILHO, 2018, p. 93). Explicando de outro modo, até 1988 entendia-se que o indígena seria integrado à sociedade e, portanto, logo mais suas terras estariam livres para o lucro.

A Constituição de 1988 é uma quebra de paradigmas porque reconhece o direito à terra - que já era reconhecido em outros instrumentos normativos ao longo dos 500 anos de invasão - e, inovando, reconhece o direito à existência, ou seja, reconhece que os povos indígenas existem e que continuarão existindo; não mais é visada a integração desses povos.

Contudo, a tese do marco temporal vai contra essa longa luta pelo reconhecimento desses direitos. Marés (2018, p. 96), tratando da Pet. 3.388, explica que os opositores visavam transformar a terra indígena em terra agrícola; a demarcação havia sido feita de forma contínua e os opositores desejavam que tivesse sido feita em ilhas, ou 
seja, demarcando somente os locais de moradia dos indígenas, desconsiderando demais espaços. Explica o autor:

A alegação era, exatamente, de que os índios tinham seus dias contados, deixariam de ser índios e se integrariam à sociedade nacional como trabalhadores e, por isso mesmo, a transferência dessas terras para produção agrícola extensiva significaria facilitar a integração que já estaria ocorrendo. (MARÉS, 2018, p. 96)

O autor explica que tal argumento não se encontra tão explícito, mas é este o sentimento, "a ideia de provisoriedade dos índios como sujeito coletivo" (SOUZA FILHO, 2018, p. 96). Tal entendimento não foi expresso somente por aqueles que figuravam contra os povos indígenas. A partir da leitura do processo, foi possível detectar que o Ministro Marco Aurélio também o expressa em seu voto ao afirmar os "benefícios" da miscigenação, cabe destaque literal:

[..] houve até mesmo ato do Marquês de Pombal voltado à miscigenação, estimulando-se o estabelecimento de relação carnal e sentimental entre portugueses e índias. Com efeito dessa política, notou-se, com o decorrer dos anos, o avanço intelectual de descendentes de índios. (BRASIL, 2009, p. 425 , grifo nosso)

Realçam aos olhos dois pontos: o colonizador é representado pelo gênero masculino, enquanto o colonizado pelo gênero feminino ${ }^{21}$; e, avanço intelectual? 0 Ministro parece entender que os indígenas não aculturados são menos inteligentes do que os demais brasileiros, entendo ser necessária uma "mistura" entre eles para que se dê o seu desenvolvimento. O ideal da integração sem mantém no voto do Ministro que entende que as TIs não devem ficar isoladas dos não indígenas:

\footnotetext{
${ }^{21}$ Acerca dessa discussão, remontamos a notícia acerca dos primeiros resultados do mapeamento genético do povo brasileiro: ROSSINI, Maria Clara. Estupro de mulheres negras e indígenas deixou marca no genoma dos brasileiros. Revista Super Interessante, São Paulo, 3 out. 2020. Ciência. Disponível em: https://super.abril.com.br/ciencia/estupro-de-mulheres-negras-e-indigenas-deixou-marca-no-genoma-dosbrasileiros/. Acesso em: 23 nov. 2020.
} 
Como, então, em pleno século XXI, considerados os avanços culturais de toda ordem, cogitar-se de isolamento da população indígena, procedendo-se à delimitação territorial contínua para afastar-se da área os não-índios? O retrocesso é flagrante, não se coadunando com os interesses maiores de uma nacionalidade integrada. (BRASIL, 2009, p. 426)

O Ministro ignora toda violência sofrida pelos povos indígenas. Ainda em seu voto (BRASIL, 2008, p. 424), compara a cidade de São Paulo, que possuía na época 11 milhões de habitantes, com a TI Raposa Serra do Sol, que possuía 19 mil habitantes e é 12 vezes maior que a cidade de São Paulo, afirmando ser difícil acreditar a existência do fato indígena, ou seja, a presença de indígenas na TI. O Ministro busca aplicar um modo de vida capitalista a um modo de vida totalmente diferente que se regula por culturas, tradições e costumes diferentes. Neste voto em especial o integracionismo é explícito!

Assim, como explica Marés ao tratar dos argumentos dos opositores aos povos indígenas no processo em questão, não se alega que os indígenas não existem, o que se discute é a continuidade da existência ou a integração:

os argumentos dos que negam o direito coletivo sobre as terras são de que eles estão a caminho da integração e, portanto, não necessitam das terras, já podem ser empregados como trabalhadores e deixarão de ser índios. (SOUZA FILHO, 2018, p. 97)

A ideia do marco temporal implica dizer que: se o povo estava fora da sua terra em 5 de outubro de 1988, ele não existe. Trata-se, então, de um marco de morte do direito e, consequentemente, a decretação da morte de um povo ou de uma comunidade.

A Constituição Federal de fato trabalhou com uma data certa em relação aos povos indígenas, contudo não diz respeito a um suposto marco temporal de ocupação, mas sim à obrigação da União em demarcar todas as terras indígenas em até cinco anos da promulgação, como consta no art. 67 do ADCT. Fato este não mencionado pelos Ministros e ignorado pela União que, além de não demarcar todas as terras, atualmente 
dificulta o processo demarcatório por meio da tese do marco temporal e das 19 condicionantes.

\section{Considerações finais}

Após todo o exposto, é possível concluir que a tese do marco temporal é contrária à Constituição de 1988 e, mais do que isso, representa um retrocesso no reconhecimento dos povos indígenas, rompe com o novo paradigma trazido em 1988 e retorna ao assimilacionismo ao permitir que povos sejam retirados de suas terras e, consequentemente, percam sua cultura e seus costumes levando ao etnocídio.

A prática integracionista permeou o tratamento do Estado Português com habitantes nativos de sua colônia Brasil e, posteriormente, o tratamento que o Brasil deu aos povos indígenas. As normativas reconheciam aos povos indígenas o direito sobre suas terras, contudo, não reconheciam o direito de ser e permanecer indígena, visava-se a integração por meio do trabalho e, após a integração, o apossamento das terras.

O marco temporal visa impor aos povos indígenas uma lógica capitalista, desconsidera anos de lutas e violências que expulsaram os povos de suas terras tradicionais e impede os chamados movimentos de retomada, por meio dos quais, povos que foram afastados de suas terras e foram considerados extintos reapareçam e voltem a se organizar.

Ressalta-se que a respeito dos povos indígenas, o único marco temporal trazido pela Constituição foi o prazo de cinco anos para que a União demarcasse todas as terras indígenas. Atualmente, 17 anos após o fim do prazo, os processos encontram-se parados e 63\% das TIs estão em situação irregular. A tese do marco temporal deve ser rejeitada pelo Supremo Tribunal Federal e pelo Estado brasileiro que tem o dever de garantir aos povos indígenas o acesso às suas terras tradicionais. 


\section{Referências}

AMADO, Luiz Henrique Eloy. O direito originário dos povos indígenas. Site Apib, [s.l.], 2020. Disponível em: https://apiboficial.org/2020/10/20/o-direito-originario-dos-povosindigenas/. Acesso em: 26 nov. 2020.

ARTICULAÇÃO DOS POVOS INDÍGENAS DO BRASIL. Nossa história não começa em 1988! Marco temporal não! Site Apib, [s.l.], 2017. Disponível em: https://apiboficial.org/2017/08/03/nossa-historia-nao-comeca-em-1988-marco-temporalnao/. Acesso em: 26 nov. 2020.

BRASIL. Constituição da República Federativa do Brasil. Promulgada em 5 de outubro de 1988. Brasília, DF: Presidência da República, 1988. Disponível em:

http://www.planalto.gov.br/ccivil_03/constituicao/constituicao.htm. Acesso em: 23 nov. 2020.

BRASIL. Decreto ${ }^{\circ} 58.824$ de 14 de julho de 1966 . Promulga a Convenção ${ }^{\circ} 107$ sôbre as populações indígenas e tribais. Brasília, DF: Presidência da República, 1966. Disponível em: http://www.planalto.gov.br/ccivil_03/Atos/decretos/1966/D58824.html. Acesso em: 28 abr. 2021.

BRASIL. Lei ${ }^{\circ} 6.001$ de 19 de dezembro de 1973. Dispõe sobre o Estatuto do Índio. Brasília, DF: Presidência da República, 1973. Disponível em:

http://www.planalto.gov.br/ccivil_03/leis//6001.htm. Acesso em 28 abr. 2021.

BRASIL. Supremo Tribunal Federal. Petição n. 3.388; Ementa: Ação Popular. Liminar Indeferida. Demarcação Da Reserva Indígena Raposa Serra Do Sol. Homologação. Portaria $N^{\circ} 534 / 2005$, Do Ministério Da Justiça. [...] Agravo regimental desprovido. Relator: Min. CARLOS BRITTO, 2009, Tribunal Pleno. Disponível em: http://redir.stf.jus.br/paginadorpub/paginador.jsp?docTP=AC\&docID=630133. Acesso em: 18 nov. 2020.

COELHO DOS SANTOS, Sílvio. Direitos Humanos e o direito dos povos indígenas no Brasil. Ilha R. Antr., Florianópolis: UFSC, p. 73-82, 2005.

CONSELHO INDIGENISTA MISSIONÁRIO. Relatório da violência contra os povos indígenas no brasil: dados de 2019. Brasília: CIMI, 2020. Disponível em: https://cimi.org.br/observatorio-da-violencial. Acesso em: 18 nov. 2020.

GUIMARAES, Alberto Passos. Quatro séculos de latifúndio. 3. ed. Rio de Janeiro: Paz e Terra, 1968. 
INSTITUTO SOCIOAMBIENTAL. Terras Indígenas no Brasil. [S.I.: s.n], 2020. Disponível em: https://terrasindigenas.org.br/. Acesso em: 19 nov. 2020.

INSTITUTO BRASILEIRO DE GEOGRAFIA E ESTATÍSTICA. Censo 2010: população indígena é de 896,9 mim, tem 305 etnias e fala 274 idiomas. [Rio de Janeiro: IBGE, 2010]. Disponível em: https://cens02010.ibge.gov.br/noticias-censo?busca=1\&id=3\&idnoticia=2194\&t=censo2010-poblacao-indigena-896-9-mil-tem-305-etnias-fala-274\&view=noticia . Acesso em: 28 out. 2020.

MORAES, José Augusto Santos. Violência e corrupção no SPI: a situação dos indígenas no sul do Mato Grosso, uma abordagem a partir do Relatório Figueiredo. (1960-1967). In: SIMPOSIO NACIONAL DE HISTÓRIA, 28., 2015, Florianópolis. Anais eletrônicos [...]. Florianópolis: [s.n.], 2015. p. 1-15.

PORTUGUAL. Carta de Lei de 10 de setembro de 1611. [S.I.: s.n.], 1611. Disponível em: http://transfontes.blogspot.com/2009/12/lei-de-10-de-setembro-de-1611.html. Acesso em: 18 nov. 2020.

RIBEIRO, Darcy. Os índios e a civilização: a integração das populações indígenas no Brasil moderno. 7 ed. São Paulo: Globo. 2017

SILVA, José Afonso. Curso de direito constitucional positivo. 34 ed. São Paulo: Malheiros, 2011.

SILVA, José Afonso. Parecer. In: CARNEIRO DA CUNHA, Manuela; BARBOSA, Samuel (orgs.). Direitos dos povos indígenas em disputa. São Paulo: Editora Unesp, 2018. p. 17-42.

SOUZA FILHO, Carlos Frederico Marés. A essência socioambiental do constitucionalismo latino-americano. Revista da Faculdade de Direito da UFG, Goiânia, v. 41, n.1, p.197-215, jan./jun., 2017.

SOUZA FILHO, Carlos Frederico Marés. Portaria 303 da AGU: apenas uma maldade? Revista de Direitos Fundamentais e Democracia, Curitiba, v. 13, n. 13, p. 33-41, janeiro/junho de 2013.

SOUZA FILHO, Carlos Frederico Marés. Marco temporal e direitos coletivos. In: CARNEIRO DA CUNHA, Manuela; BARBOSA, Samuel (orgs.). Direitos dos povos indígenas em disputa. São Paulo: Editora Unesp. p. 75-100, 2018.

SOUZA FILHO, Carlos Frederico Marés. O renascer dos povos indígenas para o direito. 1 ed. Curitiba: Juruá, 2012. 
Recebido em: 30/11/2020 Aprovado em: 13/04/2021

Universidade do Estado de Santa Catarina - UDESC Centro de Ciências Humanas e da Educação - FAED

PerCursos

Volume 22 - Número 48 - Ano 2021 revistapercursos@gmail.com 